\title{
АДМІНІСТРАТИВНО-ПРАВОВА КОНЦЕПЦІЯ РЕАБІЛІТАЦІЇ ДІТЕЙ, ЩО ПОТРАПИЛИ У КОНФЛІКТ ІЗ ЗАКОНОМ
}

Веселов М. Ю.

У статmі реабілітація дітей, що потрапили у конфлікт із законом, представлена як складова частина ювенальної юстиції, що включає суспільні відносини з виправлення, соціальної адаптації неповнолітнього правопорушника та недопущення ним повторних порушень. Така реабілітація має здійснюватися у двох основних формах: перевиховання та ресоціалізація. Пропонуються заходи щодо подальшої модернізації адміністративно-правової реабілітації зазначеної категорії дітей.

Ключові слова: дитина, неповнолітній, правопорушення, реабілітація, ресоціалізація, ювенальна юстиція.

В статье реабилитация детей, вступивших в конфликт с законом, представлена как составляющая ювенальной юстиции, включающая общественные отношения по исправлению, социальной адаптации несовершеннолетнего правонарушителя и недопущению ним повторных нарушений. Такая реабилитация должна осуществляться в двух основных формах: перевоспитание и ресоциализация. Предлагаются меры по дальнейшей модернизации административно-правовой реабилитации указанной категории детей.

Ключевые слова: ребенок, несовершеннолетний, правонарушение, реабилитация, ресоциализация, ювенальная юстиция.

The tendency of juveniles to commit repeated crimes, which has remained almost unchanged in Ukraine for a long time, indicates the insufficient level of educational impact of punishment or compulsory educational measures applied under criminal law. The purpose of this article is to work out proposals for further modernization of the administrative and legal rehabilitation of children in conflict with the law. The article proposes the concept of rehabilitation of a child in conflict with the law as a system of organizational, legal, supervisory, medical, psychological, pedagogical, educational, social and domestic measures aimed at facilitating the correction and social adaptation of a juvenile delinquency, offender or offender including the formation of a sense of dignity and awareness of the value of the individual, as well as the cultivation of respect for the rights of others, restoration of broken family communications, support social and material independence in order to prevent repeated offenses by such a person. The concept of re-education and re-socialization of children in conflict with the law combines criminal and administrative legal means. It was emphasized that the administrative-legal component in the given sphere of relations is represented by a wide range of various means, which have their own peculiarities of legal regulation and practical implementation. Measures to improve the administrative and legal concept of rehabilitation of the specified category of children should be correlated with the current principles of juvenile justice and take into account the relationship with all components of this complex social and legal institution (juvenile prevention, administrative and criminal proceedings against minors). Measures are proposed to further modernize the administrative and legal rehabilitation of this category of children.

Key words: child, minor, offense, rehabilitation, resocialization, juvenile justice.

Веселов М. Ю., 2019
Постановка проблеми та їі актуальність. Тенденція до вчинення неповнолітніми повторних злочинів, яка вже тривалий час залишається майже незмінною в Україні (у середньому 2,5\% загальної кількості злочинів, учинених неповнолітніми), свідчить про недостатній рівень виховного впливу покарання або примусових заходів виховного характеру, які застосовуються згідно 3 кримінальним законодавством. Зараз український Уряд вбачає проблему і у високому відсотку покарань, пов'язаних з ізоляцією від суспільства, що призначаються неповнолітнім. Статистичні дані свідчать про те, що під час призначення покарань не завжди враховуються психологічні та вікові особливості неповнолітніх, сприйняття ними вчинених правопорушень та час, необхідний для досягнення позитивних змін у поведінці [1]. Ізоляція неповнолітніх у закладах пенітенціарної системи порушує і без того нестійкі соціальні зв'язки та психологічні налаштування таких осіб, вимагає після звільнення тривалої соціальної адаптації, психологічної корекції, що зумовлює пошуки інших ефективних альтернатив каральній політиці.

Аналіз останніх досліджень і публікацій. Ефективність превенції будь-яких первинних чи повторних проявів делінквентності з боку дитини залежить від знання їх етимології. Поглиблені дослідження в цьому напрямі проводились Б. Бендом, Р. Корвіном та Н. Тоомбса [2, с. 597-598], Н. Родрігес [3, с. 360-375], Дж. Гарбаріно [4, с. 2], Дж. Хонгом, Дж. Райаном, Ю. Чіу, Б. Сабрі [5, с. 3], Д. Махоні та Р. Дізлі [6, с. 3]. Наведені в їхніх роботах спостереження закладають фундамент для формування правової концепції реабілітації дітей, що потрапили у конфлікт із законом.

Метою статті $\epsilon$ напрацювання пропозицій подальшої модернізації адміністративно-правової реабілітації дітей, що потрапили у конфлікт із законом.

Виклад основного матеріалу. Реабілітація (від лат. «rehabilitatio» - відновлення, поновлення) дітей, що потрапили у конфлікт із законом, є напрямом, що завершує послідовний ланцюг функціонування ювенальної юстиції. У Законі України «Про реабілітацію осіб з інвалідністю в Україні» дається визначення низки різновидів реабілітації: медичної, психолого-педагогічної, професійної, трудової, фізкультурно-спортивної, фізичної, соціальної, психологічної (ст. 1). Загальним для цих термінів $\epsilon$ те, що певною системою заходів створюються та забезпечуються умови для повернення особи до активної участі у житті, подолання особистих вад і відновлення їі соціального статусу та здатності до самостійної суспільної діяльності. Соціальна реабілітація в законодавстві згадується як одна з форм соціальної роботи із сім'ями, дітьми та молоддю та передбачає, зокрема, оптимізацію і коригування ставлення дітей та молоді до власної поведінки, формування у них 


\section{Правове забезпечення адміністративної реформи}

навичок до самообслуговування, самостійного проживання та інтеграції в суспільство, а також соціальний патронаж дітей, які відбували покарання у виді позбавлення волі (ст. 10 Закон України «Про соціальну роботу з сім'ями, дітьми та молоддю»).

Подібним до цього поняття $\epsilon$ термін «ресоціалізація», що вживається у Кримінально-виконавчому кодексі України (далі - КВК України). 3 наданої у ст. 6 цього правового акту дефініції випливає, що ресоціалізація - це процес суб'єктивно-об'єктивний, який включає певну цілеспрямовану діяльність уповноважених суб'єктів, спрямовану на особу засудженого та його умови життєдіяльності, а також зміни, які відбуваються у свідомості самої такої особи та втілюються в її поведінці (діях, рішеннях, способі життя). Необхідною умовою ресоціалізації засудженого $є$ його виправлення. Основними засобами виправлення і ресоціалізації засуджених є: встановлений порядок виконання та відбування покарання (режим), пробація, суспільно корисна праця, соціально-виховна робота, загальноосвітнє і професійно-технічне навчання, громадський вплив (ст. 6). Втім, цей перелік не $\epsilon$ повним, i до нього ще слід додати такий засіб, як соціальний патронаж, що полягає в допомозі звільненим особам шляхом здійснення комплексу правових, економічних, організаційних, психологічних, соціальних та інших заходів, зокрема надання послуг, спрямованих на їх соціальну адаптацію (ст. 1 Закону України «Про соціальну адаптацію осіб, які відбувають чи відбули покарання у виді обмеження волі або позбавлення волі на певний строк»). Отже, виправлення та соціальна адаптація особи $\epsilon$ фактичним позитивним суб'єктивний результатом - наслідком ефективної ресоціалізації.

Проте в законодавчо закріпленому понятті «ресоціалізація», в контексті ювенальної юстиції, $\epsilon$ суттєвий недолік - воно не охоплює всіх категорій дітей, які перебувають у конфлікті із законом. По-перше, йдеться лише про ресоціалізацію засуджених, а отже, неповнолітні, які скоїли кримінальне правопорушення, і щодо яких здійснюється досудове розслідування чи судовий розгляд або прийнято рішення про призначення примусових заходів виховного характеру, звільнення від кримінальної відповідальності чи закриття кримінального провадження, згаданим терміном не охоплюються. По-друге, законодавство передбачає ресоціалізацію лише особи, яка скоїла кримінальне правопорушення, а відповідно, формування позитивних змін у свідомості та поведінці неповнолітньої особи, що вчинила адміністративний проступок, запобігання його повторності залишається поза увагою цієі діяльності. Водночас процес виправлення неповнолітніх адміністративних правопорушників (включаючи й осіб, які не досягли віку адміністративної відповідальності) $\epsilon$ не менш важливим як для них самих, так і для суспільства, оскільки така стійка девіантна поведінка з часом здатна перерости в злочинну. Задля заповнення цього вакууму в правовій науці ми пропонуємо запозичити з педагогіки термін «перевиховання». У педагогіці під перевихованням розуміють виховний процес, спрямований на подолання негативних рис особистості (важковиховуваних, педагогічно занедбаних неповнолітніх, правопорушників), що сформувалися під впливом несприятливих умов виховання. 3 перевихованням починається і процес виправлення [7].
Отже, реабілітація дітей, що потрапили у конфлікт із законом, залежно від правової кваліфікації їхніх діянь (з одного боку - статусні порушення та адміністративні проступки, з іншого - кримінальні правопорушення) має здійснюватися у двох основних формах: перевиховання та ресоціалізація. При цьому спектр об'єкту впливу (категорій неповнолітніх осіб) ресоціалізації має бути суттєво розширений. Критерієм тут виступає саме формальна (правова) кваліфікація їхніх дій з боку закону, адже для дитини дуже часто грань між пустощами, проступком та злочином не $\epsilon$ очевидною, і ті ж самі пустощі за наслідками здатні призвести до кримінального правопорушення 3 необережності, a, наприклад, факт складної співучасті (із розподілом ролей) взагалі може не сприйматися неповнолітнім як злочинна діяльність.

Концепція перевиховання та ресоціалізації дітей, що потрапили у конфлікт із законом, поєднує засоби кримінально-правового та адміністративно-правового характеру.

Кримінально-правові засоби передбачають установлення в нормах права більш суворих санкцій за повторні кримінальні правопорушення, інші умови (чи неможливість їх застосування) для звільнення від кримінальної відповідальності або його фактичного виконання; заміни кримінального покарання на примусові заходи виховного характеру; вид та тривалість таких заходів, можливість звільнення неповнолітніх від кримінальної відповідальності до розгляду справи судом з покладенням на них певних обов'язків (відвідування корекційних програм, закладу освіти тощо) та ін.

У свою чергу адміністративно-правові засоби:

встановлюють: адміністративну відповідальність за адміністративні правопорушення для осіб, які досягли 16 років; заходи превентивного реагування на так звані статусні порушення певних соціальних норм із боку дітей, адміністративні правопорушення, вчинені особами, які не досягли віку адміністративної відповідальності, чи суспільно-небезпечні діяння (що кваліфікуються за КК України як кримінальні правопорушення), вчинені особами у віці до 11 років; адміністративну відповідальність представників неповнолітніх за скоєні їхніми дітьми правопорушень;

забезпечують правове регулювання відносин, спрямованих на реалізацію альтернативних форм відновлювального правосуддя щодо дітей, розроблення, впровадження та реалізацію корекційних програм щодо дітей-порушників;

визначають загальні засади соціальної адаптації неповнолітніх осіб, які відбувають чи відбули покарання у виді обмеження волі або позбавлення волі на певний строк, засади участі в соціальній адаптації цих осіб підприємств, установ та організацій, об'єднань громадян, а також фізичних осіб, забезпечують правове регулювання відносин, спрямованих на реалізацію такими особами прав і свобод, передбачених Конституцією та законами України;

регулюють численні питання організації кадрового, професійного, документально-ресурсного, соціальноадаптивного, фінансово-економічного, психологічного, медичного, освітнього, педагогічно-виховного, культурного, інформаційного забезпечення виконання покарань, пов'язаних та не пов'язаних з позбавленням (обмеженням) волі, триманням під вартою, реалізацією примусових заходів виховного характеру, примусового лікування; 
- визначають положення про організаційно-штатну діяльність, перелік норм належності матеріально-технічного забезпечення, правила внутрішнього розпорядку функціонування органів, установ та закладів пенітенціарної системи, пробації, поліції, освіти, охорони здоров'я (в тому числі спеціальних установ для дітей), соціального патронажу; права та обов'язки їхніх посадових осіб;

- визначають умови, порядок та організаційно-правові форми участі громадських інститутів, правозахисних організацій, інших неурядових суб'єктів у процесі перевиховання та ресоціалізації дітей;

створюють загальні засади контрольно-наглядової діяльності, зокрема і національного превентивного механізму, уповноважених органів державної влади та громадськості в забезпеченні гарантованих міжнародними актами, Конституцією та іншими законами України прав та найкращих інтересів дітей, що потрапили у конфлікт із законом, під час їх затримання і тимчасового тримання, застосування до них запобіжних заходів, у процесі відбування кримінальних покарань та виконання примусових заходів виховного характеру, примусового лікування (зокрема, госпіталізації до психіатричних закладів), а також забезпечують їх практичну реалізацію.

Тож адміністративно-правовий компонент у зазначеній сфері відносин представлений широким спектром різноманітних засобів, що мають свої особливості правового регулювання та практичного втілення. Крім установчої, інтегруючої, забезпечувальної функцій стосовно кримінально-правових засобів, низка адміністративно-правових засобів виконують і самостійну роль, що цілком зумовлює доцільність виділення цих правовідносин у самостійний об'єкт наукового дослідження на концептуальному рівні, що має і важливе прикладне значення. Поняття «адміністративно-правова концепція здійснення певної діяльності» розглядається як теоретико-методологічна основа правового регулювання процедур здійснення державного управління в тій чи іншій сфері, яка містить у собі: головний задум, систему керівних принципів, сукупність погоджених цілей та заходів модернізації цієї справи, заплановані індикатори результату та індикатори успіху концепції [8, с. 13].

Головний задум адміністративно-правової концепції реабілітації дитини, яка потрапила у конфлікт із законом, спрямований на сприяння виправленню та соціальній адаптації такої особи шляхом перевиховання, ресоціалізації, включаючи формування в неї почуття гідності та усвідомлення цінності особистості, а також виховання поваги до прав інших людей. Принципи концепції корелюються із загальними та спеціальними принципами ювенальної юстиції, серед яких в даному випадку доцільно виділити такі, як: забезпечення належного захисту прав, свобод і законних інтересів дітей; недискримінація; економія кримінальної репресії; відновлювальний підхід у здійсненні правосуддя за участю дітей; різнобічність та комплексність заходів; системність та наступність; забезпечення професійного підходу осіб, уповноважених на роботу з дітьми; підтримка сімей у вихованні дітей та забезпечення їх повноцінного розвитку.

Дослідження показують, що судовий процес у справах неповнолітніх часто $€$ тривалим і складним, і з неповнолітніми слід розбиратися якомога швидше.
Існують й інші методи поводження з неповнолітніми на стадії судового провадження. До них належать підходи, які використовують відновний процес. Такі моделі пропонують значні переваги всім зацікавленим сторонам і до того ж можуть зменшити кількість подальших правопорушень у порівнянні з більш традиційними методами правосуддя [6, с. 3]. Але покращенню процесу ресоціалізації дитини-порушника може сприяти не лише вдосконалення форм і особливих порядків кримінального провадження, а й активне впровадження та використання, замість кримінально-правового впливу адміністративно-правових ресурсів, превентивних заходів та мультимодальних реабілітаційних програм (програм, які поєднують кілька різних стратегій в одній: психологічної корекції, соціалізації, відновлення комунікативних зв'язків, здобуття середньої чи професійної освіти, медичного лікування від алкогольної чи наркотичної залежності тощо).

До завдань, які Уряд України визначив на сучасному етапі (до 2023 року) для забезпечення ефективної роботи з ресоціалізації неповнолітніх, включено: запровадження стандартів організації соціально-виховної роботи з неповнолітніми для забезпечення їх ресоціалізації; забезпечення розвитку центрів соціальної адаптації для неповнолітніх; підвищення ефективності виконання програм, спрямованих на формування життєвих навичок, правової свідомості, розвиток стратегії комунікації неповнолітніх засуджених для підтримки стосунків з рідними, зокрема з урахуванням гендерного складника тощо [1]. Але цих заходів може виявитися недостатньо для адміністративно-правової модернізації цієї справи. Як нами було вже зазначено, реабілітація дітей, що потрапили у конфлікт із законом, виходить за межі суто ресоціалізації засуджених неповнолітніх, а тому вимагає їх розширення.

Заходи вдосконалення адміністративно-правової концепції реабілітації вказаної категорії дітей мають корелюватися з чинними засадами ювенальної юстиції та враховувати взаємозв'язок із всіма компонентами цього складного соціально-правового інституту (ювенальною превенцією, адміністративним і кримінальним провадженнями щодо неповнолітніх).

Висновки. Отже, під реабілітацією дитини, що потрапила у конфлікт із законом, радимо розуміти систему організаційно-правових, контрольно-наглядових, медичних, психологічних, педагогічних, освітніх, соціально-побутових заходів, спрямованих на сприяння виправленню та соціальній адаптації неповнолітнього правопорушника шляхом перевиховання, ресоціалізації, включаючи формування в нього почуття гідності та усвідомлення цінності особистості, а також виховання поваги до прав інших людей, відновлення порушених сімейних комунікацій, підтримання соціальної та матеріальної незалежності, $з$ метою запобігання повторних правопорушень із боку такої особи.

3 метою модернізації адміністративно-правової реабілітації цієї категорії дітей пропонується:

1) розвивати в межах напряму «громадська підтримка» новітні організаційно-правові форми соціальної роботи з неповнолітніми правопорушниками, утворити громадсько-профілактичні центри - некомерційні організації на базі місцевих громад, які у взаємодії з органами місцевого самоврядування сприяють залученню позабюджетних фінансових і матеріаль- 


\section{Правове забезпечення адміністративної реформи}

них ресурсів юридичних та фізичних осіб (безоплатної добровільної допомоги), розробленню та реалізації мультимодальних реабілітаційних програм для дітей-правопорушників тощо;

2) створити організаційно-правові, науково-методологічні та фінансові передумови моніторингу та оцінювання ефективності мультимодальних реабілітаційних програм для дітей, які потрапили у конфлікт із законом;

3) передбачити в Кодексі України про адміністративні правопорушення механізм реалізації «реверсивного штрафу» для неповнолітніх правопорушників, які мають самостійний дохід, а також батьків, осіб, що їх замінюють, за правопорушення, що передбачені частинами 3 та 4 ст. 184 цього Кодексу - суд скасовує накладене раніше грошове стягнення повністю або частково, якщо особа, яку покарали протягом 14-30 днів, виправдовує свою поведінку або починає виконувати покладені на неї зобов'язання;

4) для реабілітації неповнолітніх правопорушників впровадити до українського адміністративно-правового законодавства систему заходів мінімального та помірного превентивного догляду (патронажу) за дитиною, а також комплексної допомоги членам їі сім'ї, коли дитині призначено такі заходи (не є заходами примусового, виховного характеру - прим. автора);

5) передбачити можливість призначення спеціалізованим колегіальним органом, що здійснює адміністрування у сфері ювенальної юстиції (у перспективі ним можуть стати територіальні координаційні ради з питань ювенальної юстиції - прим. автора), заходів мінімального превентивного догляду (патронажу) за дитиною у разі вчинення адміністративного правопорушення особою, яка не досягла віку адміністративної відповідальності, чи особою, яка вчинила суспільно небезпечне діяння, що підпадає під ознаки діяння, передбаченого КК України, до досягнення одинадцятирічного віку;

6) у нормах Кримінального та Кримінального процесуального кодексів України передбачити матеріальні та процесуальні підстави для звільнення неповнолітньої особи від кримінальної відповідальності з призначенням заходів помірного превентивного догляду (патронажу) за дитиною.

Перспективою подальших наукових розвідок у цьому напрямі стане більш поглиблене обґрунтування та опис засад призначення системи заходів мінімального та помірного превентивного догляду (патронажу) за дитиною.

\section{Література}

1. Про схвалення Національної стратегії реформування системи юстиції щодо дітей на період до 2023 року : Розпорядження Кабінету Міністрів України від 18.12.2018 р. № 1027-p. URL: https://zakon.rada.gov.ua/laws/show/ 1027-2018-\%D1\%80 (дата звернення: 23.02.2020).

2. Benda B.B., Corwyn R.F., Toombs N.J. (2001). Recidivism among adolescent serious offenders: Prediction of entry into the correctional system for adults. Criminal Justice and Behavior. 28. 588-613. DOI: 10.1177/009385480 102800503.

3. Rodriguez N. (2007). Restorative justice at work: Examining the impact of restorative justice resolutions on juvenile recidivism. Crime and Delinquency. 53. 355-379. DOI: $10.1177 / 0011128705285983$.

4. Garbarino J. (2005). See Jane hit: Why girls are growing more violent and what we can do about it. New York : The Penguin Press. 304.

5. (2013). Re-arrest among juvenile justice-involved youth: An examination of the static and dynamic risk factors / J.S. Hong at al. Residential Treatment for Children and Youth. 30 (2). 131-148. URL: https://digitalcommons.wayne.edu/ soc_work_pubs/32/ (дата звернення: 22.02.2020).

6. O'Mahony D., Deazley R. (2000). Juvenile crime and justice Northern Ireland. Belfast, Northern Ireland Office, 100. URL: https://www.academia.edu/39653749/ Juvenile_crime_and_justice_Northern_Ireland?email_work_ card=thumbnail (дата звернення: 12.01.2020).

7. Фіцула М.М. Педагогіка : навч. посібн. 2-ге вид. Київ : Видавнич. дім «Академія», 2007. 560 с. URL: https://pidruchniki.com/1494092835019/pedagogika/ perevihovannya_yogo_sutnist_funktsiyi_etapi_printsipi_ realizatsiyi (дата звернення: 22.02.2020).

8. Федотов О.П. Адміністративно-правова концепція здійснення державної митної справи: теорія та практика : дис. ... д-ра юрид. наук : 12.00.07 ; Нац. ун-т «Одеська юридична академія». Одеса, 2016. 457 с.

Веселов М. Ю., кандидат юридичних наук, доцент, доцент кафедри кримінально-правових дисциплін Криворізького факультету Національного університету «Одеська юридична академія» 